\title{
Effect of Dietary Supplementation on Physico-mechanical and Chemical Quality of Hide and Leather of Dromedary Camels
}

\author{
Moges Dereje $^{1^{*}}$, Mengistu Urge ${ }^{1}$, Getachew Animut $^{2}$ and Mohammed Y. Kurtu ${ }^{1}$ \\ ${ }^{1}$ School of Animal and Range Sciences, College of Agriculture and Environmental Sciences, \\ Haramaya University, P.O. Box 138, Dire Dawa, Ethiopia \\ ${ }^{2}$ Agricultural Transformation Agency, P.O. Box: 708, Addis Ababa, Ethiopia
}

\begin{tabular}{|c|c|}
\hline Abstract & Article Information \\
\hline $\begin{array}{l}\text { This study was aimed at evaluating the effect of concentrate supplementation under feedlot } \\
\text { condition on intake, weight gain, physico-mechanical and chemical qualities of crust and } \\
\text { finished leather of dromedary camels. Fifteen growing Ogaden camels with age range of } 24- \\
30 \text { months and mean bodyweight of } 162.8 \pm 23.8 \mathrm{~kg} \text { (Mean } \pm \text { SD) were purchased from Babile } \\
\text { camel market and used in a } 120 \text { days fattening study. The experiment was run under RCBD } \\
\text { where the camels were blocked according to their initial body weight and allotted randomly } \\
\text { within the block to three dietary treatments. The experimental feed was urea }(5 \%) \text { treated } \\
\text { maize stover (UTMS) basal diet given ad-libitum and a supplement of concentrate mix of } \\
\text { wheat bran( } 66 \%), \text { Noug seed (Gizotia abyssinica Cass.) meal }(13 \%) \text {, sorghum grain }(20 \%) \\
\text { and mineral-vitamin premix ( } 1 \%) \text {. The supplementary diet was offered to the camels at the } \\
\text { rate of } 0.5 \text { (D0.5=low level), } 1.0 \text { (D1.0=medium level) and } 1.5 \text { (D1.5=high level) percent of } \\
\text { bodyweight. Levels of supplementation did not affect the chemical and most of the physico- } \\
\text { mechanical qualities of the crust and finished leathers. Among the physico-mechanical } \\
\text { qualities, tear load perpendicular to the back bone of crust leathers was higher ( } P<0.05) \text { for } \\
\text { the Medium level compared to Low level supplement while arithmetic mean of parallel and } \\
\text { perpendicular tear loads was higher }(P<0.05) \text { for Medium and High level supplement groups } \\
\text { compared to Low level supplement. Similarly, tear resistance of finished leathers was higher } \\
\text { ( } P<0.01) \text { for High level supplement compared to Low and Medium level supplement. In } \\
\text { general, the crust and finished leathers produced by the camels in all dietary treatment } \\
\text { groups have fulfilled the required standards of the quality parameters set by various leather } \\
\text { institutes. It can be concluded that while the present feeding regime did not negatively affect } \\
\text { the leather qualities, Medium and high level of supplements resulted in better tear load and } \\
\text { tear resistance parameters of the crust and finished leather of dromedary camels. } \\
\text { teopyright@2015 STAR Journal, Wollega University. All Rights Reserved. }\end{array}$ & $\begin{array}{l}\text { Article History: } \\
\text { Received : 17-10-2015 } \\
\text { Revised : 20-12-2015 } \\
\text { Accepted : 27-12-2015 } \\
\text { Keywords: } \\
\text { Dromedary Camels } \\
\text { Supplementation } \\
\text { Physico-mechanical Quality } \\
\text { Crust Leather } \\
\text { *Corresponding Author: } \\
\text { Moges Dereje } \\
\text { E-mail: } \\
\text { mogesdr@yahoo.com }\end{array}$ \\
\hline
\end{tabular}

\section{INTRODUCTION}

The Ethiopian livestock sector contributes about $16.5 \%$ (MoFED and MoA, 2011) to the national and $47 \%$ (ICPALD, 2013) to the agricultural GDP, and is an important source of livelihood and revenue for the rural populations and the national economy. As one of the main focus area of the livestock sector, the hides, skins and leather industry in Ethiopia have huge potential towards wealth and employment creation, and economic growth. The huge population of livestock owned by the country is an indication of the potential for the development of leather industry. According to the government plan, export earning from leather export is to grow to $\$ 500$ million by the end of 2025 (MoFED, 2010) versus the current value of USD 122 million (Anonymous, 2016) indicating the need for more expansion and diversification of hides and skin production as well as the export market. This requires improved livestock management and value chain improvement initiatives (MoARD, 2014). The current annual percentage production by volume of skin from goat and sheep, and hide from cattle and camel account for 50 , 33,13 and $4 \%$, respectively (ACTESA, 2011).

Worldwide, the hide and leather of camel is considered as one of the heavy type of skins. At present, the camel leather is processed using methods defined for cattle hide and it appears to have less commercial use than cattle and small ruminant skins. However, evidence show that properly processed camel skin can produce leather that can be utilized for production of durable goods comparable to that of cattle (www.camelfarm.com; Khanna, 2000). At present camel hides and leathers are used for manufacturing of various utility items such as shoes, belts, hats, riding boots and ladies fashion garments (www.camelfarm.com). However, it has been noted that the full potential of camel hides as a product has not been realized in Ethiopia and other African countries due to their poor quality. (AU-BAR, 2006). In recent years, the marketing value of hides and leather 
products in the world in general is exceeding the percentage revenue from meat of livestock (FAO, 2010b), which may substantially increase the demand for camel skin by the industries in the very near future. The scenarios in Ethiopia show the absence of proper data keeping on camel hide and leather production, quality and utilization. Ethiopia being home to about 4.5 million camels (MoA, 2014), appropriate information on quality of camel hide and leather production potential is an essential prerequisite in general and related to feeding regimes in particular is an essential prerequisite in order to utilize this huge resource on the chemical and physico-mechanical qualities of the crust leather (leather that has been processed and dried, but not yet finished) and finished leather of the dromedary camels in eastern Ethiopia.

\section{MATERIALS AND METHODS Location of the Study}

The experiment was conducted at Haramaya University camel Farm located at Erer Guda, Babile district, at a distance of $545 \mathrm{~km}$ south east of Addis Ababa at $9^{\circ}, 14^{\prime} \mathrm{N}$ latitude and $42^{\circ}, 14^{\prime} \mathrm{E}$ longitude. The altitude ranges 1300-1600 meter above sea level. Average annual rainfall is $450 \mathrm{~mm}$ with bi-modal nature, from March to April and from July to October. The temperature ranges between $17-31^{\circ} \mathrm{C}$ (Tamire, 1986).

\section{Experimental Animals Management}

A total of 15 healthy growing intact dromedary camels of 2.5-3 years of age and average initial body weight of $162.8 \pm 23.8 \mathrm{~kg}$ (Mean \pm SD) were purchased from Babile camel market and used for a 120 days growth performance and hide and leather quality studies. Experimental camels were quarantined for 2 weeks to observe for any unhealthy condition before the animals were placed in individual feeding pen for acclimation to the experimental procedures and the feeds for another two weeks. During this period they were weighed, ear tagged, de-wormed against endo-parasite with a broadspectrum anti-helmentic (albendazole) and sprayed against ecto-parasite with acaricides (vetacidin 20\% EC) as a prophylactic measures and vaccinated for pasteurelosis and anthrax based on the recommendation of veterinarians. During the 2 weeks of the adaptation period, animals were offered the supplement feeds in such a way that the maximum per day for the individual animals is reached at the end of the period. Animals were housed individually in shaded floor pens for the duration of the experiment. The camels were slaughtered at an average body weight of $255.3 \pm 23.5 \mathrm{~kg}$. All management procedures were carried out according to the institution and international guidelines for animal welfare.

\section{Feeds, Experimental Design and Treatments}

Animals were individually fed with concentrate supplement composed of wheat bran (60\%), sorghum grain (20\%), Noug seed meal (Gizotia abyssinica Cass.) $(13 \%)$ and mineral and vitamin premix (1\%) (Table 1) and maize stover treated with $5 \%$ urea (urea treated maize stover; UTMS). The UTMS was offered ad-libitum while the concentrate supplement was given according to the body weight of the animal. Water was given twice per day and the remaining water was removed after the animals drunk as much as they wanted.

Table 1: Chemical composition (\% for DM and \% DM for others) of experimental feeds

\begin{tabular}{ccccccc}
\hline & \multicolumn{6}{c}{ Feed type } \\
\cline { 2 - 7 } Variable & UnTMS & UTMS & $\begin{array}{c}\text { Wheat } \\
\text { bran }\end{array}$ & $\begin{array}{c}\text { Sorghum } \\
\text { grain }\end{array}$ & $\begin{array}{c}\text { Noug } \\
\text { seed cake }\end{array}$ & $\begin{array}{c}\text { Concentrate } \\
\text { mix }\end{array}$ \\
\hline DM & 91.3 & 65.2 & 88.1 & 88 & 91.7 & 87.7 \\
CP & 4.14 & 9.44 & 18.1 & 9.63 & 34.4 & 16.3 \\
OM & 85.49 & 59 & 82.83 & 82.68 & 82.27 & 82.55 \\
Ash & 5.78 & 6.25 & 5.3 & 5.37 & 9.43 & 5.15 \\
EE & 0.6 & 1.2 & 4.5 & 4.3 & 5.1 & 4.01 \\
CF & 42.2 & 20.24 & 11.32 & 3.5 & 21.33 & 7.88 \\
NDF & 82.7 & 79.4 & 43.1 & 40.3 & 47.5 & 31.4 \\
ADF & 45.7 & 52.5 & 22.3 & 10.5 & 15.4 & 11 \\
NFE & 38.5 & 55.1 & 48.9 & 65.2 & 21.4 & 54.3 \\
ME (MJ/kg) & 6.7 & 10.5 & 11.7 & 11.8 & 9.8 & 11.2 \\
\hline \multicolumn{7}{c}{ DM=Dry matter; CP=Crude protein; OM=Organic matter; EE=Ether extract; } \\
CF=Crude fiber NDF=Neutral detergent fiber; ADF=Acid detergent fiber;
\end{tabular}

A randomized complete block design (RCBD) was used for the experiment. At the end of the quarantine period, the initial body weight of the camels were listed in an ascending order with corresponding animal's identification number and grouped into 5 blocks of three animals. The 3 members of each block were randomly allocated to one of the 3 treatments, namely concentrate supplementation in amount of $0.5 \%$ (Low), $1 \%$ (Medium) and $1.5 \%$ (High) body weight per day on a DM basis. Total Dry matter (DM) and crude protein (CP) intake and body weight gain were measured and reported in a companion paper (Moges et al., unpublished).

\section{Chemical Analysis of the Feedstuffs}

Duplicate samples of each feedstuff were analyzed according to the procedures of AOAC (1990) for dry matter (DM), crude protein $(\mathrm{CP})$ as $\mathrm{N} \times 6.25$, ash, organic matter (OM), total nitrogen by Kjeldahl method, ether extract (EE) and crude fiber (CF). Acid detergent fiber (ADF) was analyzed according to Robertson and Van Soest (1981) and neutral detergent fiber (NDF) according to the procedure of Van Soest et al. (1991). Nitrogen free extract (NFE) was calculated by difference according to Dhont and Berghe (2003). Metabolizable energy (ME) contents of the feed stuffs were calculated according to MAFF (1975) and Ellis (1980).

Handling and Processing of Crust \& Finished Leather

After completion of the growth experiment, camels were slaughtered and hides were flayed in a very careful manner. Wet salting method was used for preservation of the hides to prevent putrefaction until it was transported to 
the Ethiopian Leather and Leather Products Technology Institute (LLPTI) for further processing and quality determination. Before spreading the salt, excess flesh and fat were gently removed and the skins were washed with clean tap water according to the Ethiopian Standard Authority (ES) code ES-B.J6. 003 (1990). The amount of salt used was $50 \%$ of the mass of a fresh hide following the procedure developed by Ethiopian Standard Authority (ES). Hides were processed into leather using the LLPTI recipe prepared for cattle hide after passing through major processing stages such as: deharing (removal of hair), fleshing (mechanical removal of unwanted flesh, connective tissue and fat by hand, knife or fleshing machine), liming (hide is soaked in an alkali solution to avoid unwanted proteins and keratin for the penetration of tanning agents), bating (enzyme treatment to soften the leather), degreasing (removing the natural fats), washing, pickling (a process of acidification of the scudded pelt in drum with salt solution and pre-diluted acid to preserve and condition the pelt for tanning, the process lowers the $\mathrm{pH}$ value and help penetration of tanning agents), tanning (a process by which skins are converted to leathers by adding tanning or materials soaking the hide in a tanning agent such as chrome solution), neutralization (adjusting $\mathrm{pH}$ to a value between 4.5 and 6.5), fat liquoring (fixing fats/oils and waxes to the leather fibres), drying (the leather is dried to various moisture levels) and finishing (all processes administered to leather after tanning such as colouring, masking imperfections, oiling, etc...). The crust and finished leather qualities were assessed for chemical and physico-mechanical characteristics in LLPTI physical laboratory according to the laboratory guidelines. The locations of the samples were determined according to ISO-2418 (2002). Samples were taken in accordance with ISO-2418 (2005). Triplicate samples were taken from each crust and finished leather parallel (horizontal) and perpendicular (vertical) to the backbone.

\section{Chemical and Physico-mechanical Qualities of the Crust and Finished Leather \\ Chemical Qualities}

The moisture content or volatile matters of the chrome crust hide were determined according to the test method of SLC-3; SLC (1996a). The moisture content was taken to be the percentage weight lost by the samples when dried at $102 \pm 2^{\circ} \mathrm{C}$ to constant weight. The fat content of the moisture-free samples were determined using standard Soxhlet extraction method according to the Society for Leather Chemical test (SLC-4; SLC, 1996b). The fat content was taken to be the percentage weight of substances extracted from the samples using the solvent dichloromethane. The chrome-oxide $\left(\mathrm{Cr}_{2} \mathrm{O}_{3}\right)$ content of the leather after tanning, defined by the quantity of the chromium compound was determined by oxidizing the leather ash and iodometric titration of the hexavalent chromium ions based on official method of analysis (SLC208; SLC, 1996c). All of the chemical tests were conducted at the Ethiopian LLPTI laboratory. The chromic oxide content of the leather was calculated as a percentage of the original leather weight

\section{Physico-mechanical Quality}

Tensile strength and percentage elongation were assessed using a dynamometer (ISO 3376; ISO 2002b). Tensile strength was expressed in relation to the diameter at the narrowest part of the dumbbell-shaped piece of leather and the thickness of the sample. Elongation at grain break was determined during the test for tensile strength. A rectangular leather sample with a small slit cut in the middle of it was used for tear strength test. The sample was pulled apart by a clamp attached to its base and another clamp inserted through the slit. The point at which the slit started to tear was defined as the tear strength. The tear strength was expressed in relation to average leather thickness (ISO 3377-2; ISO, 2002c). Distension at crack of the leather grain was determined by ball burst test using a lastometer (ISO-3379; ISO, 2005c).

Average tear load/arithmetic mean and tear resistance were determined using test method of ISO-3377-2 (2002c) and ISO-3376 (2000), respectively. Samples were conditioned according to ISO-2419 (2002). Thickness of samples was assessed according to BASF (2012) or ISO2585 (2002) using a standard measuring gauge.

Absorption of water (\%) by leather was determined according to the standard procedure (BASF, 2012) or ISO 5403; ISO, 2002d) for light or flexible leather. Water absorption value measures the ability of the skin or leather to absorb water within 24 hours after immersion in a sample glass apparatus called kubelka.

\section{Statistical Analysis}

Data were analyzed using the one way analysis of variance procedure of SAS software (SAS, 2008). The model for data analysis was: $Y_{i j}=\mu+t_{i}+b_{j}+e_{i j}$, where $Y_{i j}$; the response variable, $\mu$ : overall mean, $\mathrm{t}_{\mathrm{i}}$ : treatment effect, $b_{j}$ : block effect and $e_{i j}$ : error. Duncan's multiple-range test (Duncan, 1955) was used to test the significant differences between means when an F-test declared significance at $P<0.05$.

\section{RESULTS AND DISCUSSIONS}

\section{Feeds Intake and Body Weight Gain}

Details of the feed intake and body weight gain of camels were reported in a companion papers (Moges et al., unpublished). The urea treated maize stover consumed by the animals had a CP content of $9.44 \%$, which is higher than a threshold required for optimum function of rumen microorganisms (Whiteman, 1980) indicating that urea treatment increased crude protein content of stover. The concentrate mix, as expected, had a moderate source of $\mathrm{CP}$ and $\mathrm{ME}$ and the animal consumed the supplement with no refusal every day during the experiment period. The ME and CP content of the concentrate mix used in the present study were comparable with that used by Intisar et al. (2007) for fattening young camels, which contained 11.0 MJ ME and $16.5 \%$ CP while the CF $(11.5 \%)$ was lower.

The total daily DM intake was $5.24,5.66$, and $6.30 \mathrm{Kg}$ $(\mathrm{SEM}=0.48)$ for camels supplemented with concentrate at a rate of $0.5,1$ and $1.5 \%$ of body weight and it is significantly increased with increasing level of concentrate feeding $(p=0.000)$. The camels in Low, Medium and High level of supplement grew by $0.68,0.80,0.84 \mathrm{~g} /$ day $(\mathrm{SEM}=0.08)$ and the gain was lower $(p=0.022)$ in Low level of supplement group than the other groups.

\section{Chemical Qualities of the Crust Leather}

Supplementation has no significant effect on chemical qualities of the crust leather (Table 2). Though there were few general studies conducted on hide and leather of camels (Salehi et al., 2013; Anastasia et al., 2013; Hekal, 2014; Nasr, 2015), literature sources relating levels of nutritional supplements to camel crust and finished leather 
Moges Dereje et al.,

qualities appears to be lacking. Even with other species of livestock, there were few sources dealing with these parameters. Therefore, sources in similar areas of studies, but with different species were utilized to compare and contrast the findings of the present study. Natural fat content that cannot be removed sufficiently during the process affects the extent of the leather to accept fatliquor substances and degreasing operation that are carried out to eliminate the excess fat substances. In the current study, the fat contents were not significant $(P>0.05)$ among treatments, but numerical values for fat percentage were lower in Low level supplement group than the Midium and High level dietary groups indicating higher levels of concentrate feeding may produce leather with higher fat content. Previous work in goat (Tadesse et al., 2015; Stosic, 1994) and sheep (Fasil et al., 2015; Tsegay et al., 2012) noted that low level concentrate feeding resulted in a numerically lower skin fat than high concentrate feeding. Leather with high chrome oxide content has better resistance to decomposition (Fasil et
Sci. Technol. Arts Res. J., Oct-Dec 2015, 4(4): 18-24

al., 2015). The values obtained by all dietary treatment levels in the current study resulted in chrome-oxide above the required values $(>3.5 \%)$ for garment leather (BASF, 1984 ) and $>2.5 \%$ for shoe upper leather (ES-1188, 2005). The moisture content is an important characteristic of leathers. The amount of moisture determines the quality of leathers. Extremely dried leather is susceptible to embrittlement (ability to break/tear) of the grain and excessive content of moisture may cause formation of mould. The ideal moisture content of leather is $12-14 \%$ (SATRA Spotlight, 2006). The moisture content of the camel leather in the current study was well within the requirement $(12 \%)$ set by the Ethiopian Standards Authority (ES-1195, 2005). Nasr (2015) noted higher moisture content $(14.21 \%)$ of young male Egyptian camel (24-30 month) leather made from hides collected from abattoir than the current result. Higher moisture content of leather was also reported for poorly fed goat (Stosic, 1994) and sheep (Fasil et al., 2015).

Table 2: Effects of supplementation on chemical property of camel crust leather

\begin{tabular}{|c|c|c|c|c|c|}
\hline \multirow{2}{*}{ Parameter } & \multicolumn{3}{|c|}{ Dietary treatment levels* } & \multirow{2}{*}{ SEM $^{\dagger}$} & \multirow{2}{*}{$P$-value } \\
\hline & Low & Medium & High & & \\
\hline No. of camels & 5 & 5 & 5 & & \\
\hline Chromic oxide (\%) & 5.42 & 5.44 & 5.30 & 0.38 & 0.819 \\
\hline Fat content $(\%)$ & 16.98 & 17.06 & 17.34 & 0.34 & 0.245 \\
\hline Moisture content (\%) & 12.72 & 12.46 & 12.28 & 1.18 & 0.367 \\
\hline
\end{tabular}

\section{Physico-mechanical Qualities of Crust and Finished Leather}

Tensile Strength and Percentage Elongation

The physico-mechanical qualities of the crust and finished camel leather are shown in Tables 3 and 4. Levels of supplementation have not brought significant $(P>0.05)$ effect on tensile strength and percentage elongation on the crust and finished leathers. This might suggest that the levels of supplementation used in the current study are all good enough to impact tensile strength and percentage elongation of leathers, which might be an indication for leather to be less sensitive to supplemental concentrate levels as compared to body weight gain. Salehi et al. (2013) reported comparable tensile strength $\left(21.47 \mathrm{~N} / \mathrm{mm}^{2}\right)$ but superior leather elongation $(61 \%)$ to the current result for fattened adult dromedary camels. Study conducted by Tsegay et al. (2012) on lamb skin found numerically better tensile strength and percentage elongation of supplemented lamb skin.

Table 3: Effects of supplementation on physico-mechanical qualities of camel crust leather

\begin{tabular}{|c|c|c|c|c|c|}
\hline \multirow{2}{*}{ Parameter } & \multicolumn{3}{|c|}{ Dietary treatment levels* } & \multirow{2}{*}{ SEM $^{* *}$} & \multirow{2}{*}{ p-value } \\
\hline & Low & Medium & High & & \\
\hline No. of camels & 5 & 5 & 5 & & \\
\hline Tensile strength $\left(\mathrm{N}^{\dagger} / \mathrm{mm}^{2}\right)$ & 21.66 & 22.08 & 21.16 & 3.60 & 0.920 \\
\hline Percentage elongation at break (\%) & 52.98 & 54.18 & 55.40 & 4.99 & 0.750 \\
\hline Mean tear load1 $(\mathrm{N})$ parallel to back bone & 65.38 & 75.80 & 75.32 & 9.07 & 0.160 \\
\hline Mean tear load2 $(\mathrm{N})$ perpendicularto back bone & $71.62^{b}$ & $93.00^{\mathrm{a}}$ & $90.22^{\mathrm{ab}}$ & 11.60 & 0.026 \\
\hline Av. tear load/force $(\mathrm{N})$ [mean of 1 and 2] & $68.44^{\mathrm{b}}$ & $84.40^{\mathrm{a}}$ & $82.78^{\mathrm{a}}$ & 9.49 & 0.039 \\
\hline Tear resistance/strength $(\mathrm{N} / \mathrm{mm})$ & 43.16 & 48.80 & 47.04 & 5.48 & 0.387 \\
\hline Water absorption (\%) & 81.06 & 84.82 & 83.90 & 3.74 & 0.291 \\
\hline Distention at crack (mm) & 10.84 & 10.44 & 10.42 & 0.74 & 0.612 \\
\hline Load at crack (N) & 385.52 & 439.98 & 384.28 & 50.46 & 0.170 \\
\hline Distention at burst $(\mathrm{mm})$ & 12.00 & 11.30 & 11.72 & 0.50 & 0.123 \\
\hline Load at burst $(\mathrm{N})$ & 462.60 & 514.52 & 545.06 & 71.66 & 0.225 \\
\hline Thickness (mm) & 1.58 & 1.64 & 1.66 & 0.12 & 0.562 \\
\hline
\end{tabular}

${ }^{a b}$ Different letters within a row denote significant difference at $(\mathrm{P} \leq 0.05)$; *Low $=$ adlibitum UTMS + concentrate mix of $0.5 \%$ of bodyweight; Medium = adlibitum UTMS + concentrate mix of $1.0 \%$ of bodyweight; High = adlibitum UTMS + concentrate mix of $1.5 \%$ of bodyweight in DM basis per day; ${ }^{* *} \mathrm{SEM}=$ standard error of the mean, ${ }^{\dagger} \mathrm{N}=$ Newton 
Table 4: Effects of supplementation on physico-mechanical qualities of finished camel leather

\begin{tabular}{|c|c|c|c|c|c|}
\hline \multirow{2}{*}{ Parameter } & \multicolumn{3}{|c|}{ Dietary treatment levels* } & \multirow{2}{*}{ SEM $^{* *}$} & \multirow{2}{*}{ p-value } \\
\hline & Low & Medium & High & & \\
\hline No. of camels & 3 & 3 & 3 & & \\
\hline Tensile strength $\left(\mathrm{N}^{\dagger} / \mathrm{mm}^{2}\right)$ & 24.07 & 24.00 & 25.37 & 0.97 & 0.232 \\
\hline Percentage elongation at break (\%) & 52.67 & 50.67 & 76.80 & 6.33 & 0.519 \\
\hline Mean tear load1 $(\mathrm{N})$ parallel to back bone & 74.77 & 76.30 & 83.97 & 6.26 & 0.235 \\
\hline Mean tear load2 $(\mathrm{N})$ perpendicular to back bone & 76.67 & 89.17 & 98.30 & 11.77 & 0.148 \\
\hline Av. tear load/force $(\mathrm{N})$ [mean of 1 and 2] & 75.28 & 83.33 & 91.27 & 8.67 & 0.157 \\
\hline Tear resistance/strength $(\mathrm{N} / \mathrm{mm})$ & $56.00^{\mathrm{b}}$ & $63.57^{\mathrm{b}}$ & $74.37^{\mathrm{a}}$ & 4.03 & 0.004 \\
\hline Water absorption (\%) & 79.07 & 80.37 & 75.27 & 3.78 & 0.301 \\
\hline Distention at crack (mm) & 10.40 & 9.77 & 10.03 & 0.53 & 0.399 \\
\hline Load at crack $(\mathrm{N})$ & 396.23 & 413.70 & 418.63 & 37.77 & 0.758 \\
\hline Distention at burst (mm) & 11.67 & 11.47 & 11.43 & 0.59 & 0.876 \\
\hline Load at burst $(\mathrm{N})$ & 535.37 & 545.23 & 586.40 & 54.89 & 0.521 \\
\hline Thickness (mm) & 1.33 & 1.43 & 1.30 & 0.09 & 0.273 \\
\hline
\end{tabular}

${ }^{a b}$ Different letters within a row denote significant difference at $(\mathrm{P} \leq 0.05)$; *Low = adlibitum UTMS + concentrate mix of $0.5 \%$ of bodyweight; Medium = adlibitum UTMS + concentrate mix of 1.0\% of bodyweight; High = adlibitum UTMS + concentrate mix of $1.5 \%$ of bodyweight in DM basis per day; ${ }^{* *}$ SEM = standard error of the mean, ${ }^{\dagger} \mathrm{N}=$ Newton.

\section{Tear Loads and Tear resistance}

Differences $(P>0.05)$ were not observed among the dietary treatments in the crust leather tear load (force) parallel to back bone and tear resistance (strength). Significant differences $(P<0.05)$ were observed among the diet level groups for tear load perpendicular to the back bone, whereby the Medium level group exhibited greater value of the crust leather than the Low supplemental group but not from the High level group. The arithmetic mean of the parallel and perpendicular tear load of the crust leather in the Medium and High level dietary groups were higher $(P<0.05)$ than the Low supplemental group. Tear Strength is the median force required to propagate a cut in a specified test specimen. Significant differences $(P<0.01)$ were observed among the dietary treatment groups with regard to tear resistance of the finished leather whereby High level dietary group resulted in higher values as compared to the other two groups signifying the importance of higher level of dietary supplements in camel leather strength. Tear resistance results of the finished leather of the current study were comparable with the results obtained by Hekal (2014) for un-supplemented adult Maghrebi $(68.14 \mathrm{~N} / \mathrm{mm})$ and Sudanese $(70.57 \mathrm{~N} / \mathrm{mm})$ dromedary camels. The values registered by the three dietary groups in the current study for tear resistance of camel crust and finished leather were well above the standard recommended for shoe upper leather $(>25 \mathrm{~N} / \mathrm{mm})$ and garment leather $(>35 \mathrm{~N} / \mathrm{mm})$ set by BASF (2012). Comparison of the parallel and perpendicular sampled crust and finished leather of the current study revealed that the vertical samples required more tear forces (stronger) than the parallel samples. These results were supported by Tsegay et al. (2012) who noted that vertical sampling direction requires numerically higher force $(8.9 \mathrm{~N})$ to tear when compared to the horizontally sampled skin $(7.5 \mathrm{~N})$. Nevertheless, results obtained by Craig et al. (1987) and Oliveira et al. (2007) showed that horizontal sampling direction has higher $(P$ $<0.05$ ) values compared to the vertical direction of sampling. The possible reason for the discrepancy could be the difference in the arrangement of the collagen fibers cross linkage of the camel crust and the goat skin.
Distention and Strength of Grain, Thickness and Water Absorption

There were no significant $(P>0.05)$ differences among dietary treatments with regard to load at crack and load at burst values of the crust and finished leather grains. This could be for the reason that all the current dietary treatment levels might have produced good enough leathers with similar values of grain layer. This result did not agree with the report of Stosic (1994) who found that leathers made from the skins of goats kept on the high nutritional regime tended to resist higher loads at crack and burst of the grain than leathers from goats in the Low dietary supplement. Similarly, in the case of distension performance of the grains, all treatment groups exhibited equally good distention at crack and burst values of the crust and finished leathers grains. On the contrary, Stosic (1994) reported that grain layers of goats' leather from Low level of nutrition exhibited higher distention at crack and burst. This result of Stosic (1994) could be explained by the fact that as hides become thicker (due to age or high level of nutrition) the extensibility of the leather reduces which was not evident in the current camels' leather. The amount of fat may influence the distension ability by blocking the amount of material to be removed from the grain layer during processing. This makes the fiber structure less open and less able to distend. There were also no significant differences among the camel groups, with regard to the thickness of crust and finished leather. This result might also indicate that the levels of the supplements might be enough to produce comparable values among the groups. In the report of Stosic (1994), however, high level of concentrate supplement resulted in better thickness of goats leather. The thickness results in the current study were within the range 1.0-2.2 $\mathrm{mm}$ reported for Tunisian camels (Leather.com, 2006) and $>1.1 \mathrm{~mm}$ recommended by INESCOP (Center for Technology and Innovation, for cattle leather). On the other hand, the current result did not agree with the reports of Salehi et al. (2010) who observed 3.3 and $1.75 \mathrm{~mm}$ thickness for the crust and leather, respectively, of un-supplemented Iranian dromedary camels. Possible reasons for the differences could be variations in method of processing and analysis, breed type, environment, age, sex and sample sites (Adel and Elboushi, 1994). No 
Moges Dereje et al.,

differences were observed for the water absorption capacity of the crust and finished leather among the dietary groups. Even then, these present results from all levels of the supplement were in agreement with BASF (2012) standards which noted that value for water absorption of shoe upper leather to be $<85 \%$. According to the chemical and physico-mechanical test results of the camel crust and finished leather (Table 2, 3 and 4), almost all values were within and above the minimum standard requirement values set by the Institutes for Assays and Research on Footwear Production (BASF, 2012; ES (Ethiopian Standards Authority), 2005; UNIDO, 1994 and IS (Indian Standards Institution), 1986).

\section{CONCLUSSION}

The present study indicated that all levels of dietary supplements, despite their differences, produced crust and finished leathers with chemical and physicomechanical characteristics comparable and even with better quality standards than required by the leather industries. In general, medium and high level dietary supplementation plus ad-libitum UTMS could be one of the better feeding strategies to improve the growth performance and tear load of the crust and tear resistance of the finished leather qualities of the dromedary camels.

\section{Acknowledgment}

The first author is grateful to SIDA Haramaya University project $\mathrm{PhD}$ Scholarship Program for sponsoring the study. Haramaya University and Ethiopian Institute of Agricultural Research are also acknowledged for partial financial support of the project.

\section{Conflict of Interest}

Authors declared that there is no any conflict of interest.

\section{REFERENCES}

ACTESA (Alliance for Commodity Trade in Eastern and Southern Africa) (2011). Botswana livestock value chain base line study. Eighth Session of the Committee on Food Security and Sustainable Development and Regional Implementation Meeting for the Twentieth Session of the Commission on Sustainable Development. Addis Ababa, Ethiopia.

Adel, R., Elboushi, Y. (1994). Poultry feed from waste. In: "Hide and Tanning by Products". Chapman and Hall, London, UK, PP. 154-156.

Anastasia, W.K., Francis, M., Ellias, N. (2013). Camel hides: Production, marketing and utilization in pastoral regions of northern Kenya. Pastoralism: Research, Policy and Practice. Accessed on August 15, 2014 fromhttp://www.pastoralismjournal.com/content/3/1/25

Anonymous (2016). Investing in leather industry to meet international standard quality. Ethiopian Herald Magazine, February 5, 2016 issue. Accessed on April 15, 2016 from http://www.ethpress.gov.et/herald/index.php /technology/item/3642-investing-in-leather-industry-tomeet-international-standard-quality

AOAC (1990). Official method of analysis, $15^{\text {th }}$ ed. (Helrich, K., ed.), Pub. By Association of Official Analytical Chemists, Washington, DC.

AU-IBAR (African Union Interafrican Bureau for Animal Resources) (2006). Kenya livestock sector study: An analysis of pastoralists' livestock products, market value chains and potential external markets for live animals and meat. Nairobi, Kenya. 193p.
Sci. Technol. Arts Res. J., Oct-Dec 2015, 4(4): 18-24

BASF (Baden Aniline and Soda Factory) (1984). Vademecum para el tecnico en curticion. $2^{\text {nd }}$ ed. (BASF, Ludwigshafen, Germany).

BASF (Baden Aniline and Soda Factory) (2012). Booklet book for the leather technologist. $4^{\text {th }}$ ed. Revised and enlarged. Ludwigshafen, Germany. 454p. Accessed on

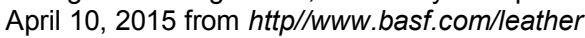

Dhont, J., Berghe, E.V. (2003). Analytical Techniques in Aquaculture Research Laboratory of Aquaculture \& Artemia Reference Center, Ghent University, Belgium. Accessed on January 12, 2014 from http://www. aquaculture.ugent.be/Education/coursemateria I/online\%20courses/ATA/analysis/NFE.htm

Duncan, D.B. (1955). The multiple range and F-test. Biometrics 11: 1-42.

Ellis, N. (1980). The nutrient composition of Sudanese animal feeds. Bul. I. Northern and Central Sudan.Animal Nutrition Research Laboratory, Kuku, Khartoum North. Appendix 1 , p. 19.

ES (Ethiopian Standard Authority) (1990). Raw hides and skins preparation ES-B.J6. 003 (1990), Leather and Leather products Technology Institute, Addis Ababa, Ethiopia.

ES (Ethiopian Standard Authority) (2005). Determination of moisture content of leather, ES 1195: (2005). Leather and Leather products Technology Institute, Addis Ababa, Ethiopia.

ES (Ethiopia Standards Authority) (2005). Determination of chrome oxide content of leather, ES-1188 (2005). Leather and Leather products Technology Institute, Addis Ababa, Ethiopia.

FAO (Food and Agriculture Organization of the United Nations) (2010b). World Statistical Compendium for Hides, Skins, Leather and Leather Footwear. Tropical and Horticultural Products Service, Commodities and Trade Division (ESC), FAO, Rome, Italy.

Fasil, N., Mengistu U., Yoseph, M., Getachew, A. (2015). Effects of Different Feeding Regimes on Leather Quality of Finished Blackhead Ogaden Sheep. Science, Technology and Arts Research Journal 4(2): 222-227.

Hedi, A., Khemais, K. (1990). Intake, digestion and feeding behaviour of the one-humped camel stall-fed straw-based diets. Livestock Research for Rural Development 2(2) 1990. Accessed on April 1, 2016 from http://www.Irrd.org//rrd2/2/abdouli.htm

Hekal, S.A. (2014). Histological study of the skin and leather characteristics in two types of Arabian Camels (Camelus dromedarius). Journal of American Sciences 10(9): 41-48.

ICPALD (IGAD Centre for Patoral Areas and Livestock Development) (2013). The Contribution of Livestock to the Ethiopian Economy. Policy Breef Series, Policy Brief No: ICPALD 5/CLE/8/2013, Nirobi, Kenya.

INESCOP (Center for Technology And Innovation), "Manual For Oxazolidine Tanned Leather: Enviromentally Friendly Oxazolidine-Tanned Leather (LIFE08 ENV/E/000140)", accessed on December 29 2015, available at. Accessed on April 15, 2016 from http://ec.europa.eu/ environment/life/project/Projects/index.cfm?fuseaction=ho me.showFile\&rep=file\&fil=OXATAN Manual Curticion.pdf

Intisar, Y.T., Ahmed, R.M., Agab, H., Tagaddin, M. (2007). Feedlot performance of dromedary camel calves fed different dietary regimes. Journal of Science and Technology 8(2):102-109.

ISO (International Organization for Standardization) (2000) Test methods of tear strength, ISO 3376 . Leather and 
Leather Products Technology Institute, Addis Ababa, Ethiopia.

ISO (International Organization for Standardization) (2002). Methods for sample conditioning, ISO 2419. Leather and Leather Products Technology Institute, Addis Ababa, Ethiopia.

ISO (International Organization for Standardization) (2002). Sampling for physico- mechanical test, ISO 2418. Leather and Leather Products Technology Institute, Addis Ababa, Ethiopia.

ISO (International Organization for Standardization) (2002). Test method for measuring of thickness of samples, ISO 2585. Leather and Leather Products Technology Institute, Addis Ababa, Ethiopia.

ISO (International Organization for Standardization) (2002b). Test methods of tensile strength and percentage elongation, ISO 3376. Leather and Leather Products Technology Institute, Addis Ababa, Ethiopia.

ISO (International Organization for Standardization) (2002c). Sampling methods for tear load and tear resistance, ISO 3377-2. Leather and Leather Products Technology Institute, Addis Ababa, Ethiopia.

ISO (International Organization for Standardization) (2002d). Test methods for water absorption, ISO 5403. Leather and Leather Products Technology Institute, Addis Ababa, Ethiopia.

ISO (International Organization for Standardization) (2005). Sampling methods and sampling location for tensile strength, ISO 2418. Leather and Leather Products Technology Institute, Addis Ababa, Ethiopia.

ISO (International Organization for Standardization) (2005c). Test methods of distension and strength of grain, ISO 3379. Leather and Leather Products Technology Institute, Addis Ababa, Ethiopia.

IS (Indian Standards Institution) (1986). Specification for shoe upper leather for direct moulding processes (Reaffirmed 2009) (First Revision), New Delhi 110002. UDC 675.244: 685.312.14.

Khanna, N.D. (2000). Camel production in India. Livestock sector. In: Arid Ecology Resource, Hazard, and Rural Development policy by SC Kalwar, MK Khandelwal and KL Gupta, 2000, 2 volumes 543 p vol. II Agriculture and Irrigation Project 2000 pp. 506-509.

Leather com (2006). Austria. CIF In Trade GmbH. Schwarzwaldstr. 13-76287 Rheinstetten. Germany. http://www.leather com.

MAFF (1975). Energy allowances and feeding systems for Ruminants. Ministry of Agriculture, Fisheries and Food. Technical Bulletin 33. London, UK.

MoARD (Ministry of Agriculture and Rural Development) (2014). Ethiopian Livestock Master Plan (LMP): Roadmaps for growth and transformation (2015-2020). Developed by the Livestock Master Plan team. Livestock Resources Development Sector. Addis Ababa, Ethiopia.

MoFED (Ministry of Finance and Economic Development) (2010). Growth and Transformation Plan (GTP) of Ethiopia. Addis Ababa, Ethiopia:

MoFED (Ministry of Finance and Economic Development) and MoA (Ministry of Agriculture) (2011). A Review to Improve Estimation of Livestock Contribution to the National GDP. IGAD Livestock Policy Initiative, Addis Ababa, Ethiopia.

Nasr, A.I. (2015). Evaluation of Egyptian Camel Hides for Leathers Manufacturing. World Applied Sciences Journal 33 (8): 1329-1333.
Robertson, J.B., Van Soest, P.J. (1981). The detergent system of analysis. In: W.P.T. James and O. Theander, Editors, The Analysis of Dietary Fibre in Food, Marcel Dekker, New York, Basel, pp. 123-158 (Chapter 9).

Salehi, M., Zakheri, N., Taherpour Dari, N., Ansari Renani, H.R., Lotfiilah Nia, B., Eghbaleh, A. (2010). Evaluation of Iranian Native Goat's Skin for Grading and Sorting. Animal Science Research Institute, Agriculture Research Education and Experiment Organization, Iran, PP. 45-51. (in Persian with English Abstract). Accessed on Dec, 2014 from http://jast.modares.ac.ir/article 5025 992.html

Salehi, M.A., Mirhadi, F., Ghafouri-Kesbi, M., Asadi, F., Babak, A. (2013). An Evaluation of Live Weight, Carcass and Hide Characteristics in Dromedary vs. Bactrian $\times$ Dromedary Crossbred Camels. Journal of Agricultural Science and Technology 15: 1121-1131.

SAS Institute (2008). SAS User's Guide. Version 9.1.3. SAS Institute Inc., Carry, NC.

SATRA Spotlight (2006). The chemical testing of leather. SATRA Technology centre. Accessed on March 3, 2015 from www.satra.co.uk

SLC (Society for Leather - Chemical test) (1996a). Official Methods of Analysis (SLC-3) for determination of moisture content and volatile matters in leather. Leather and Leather products Technology Institute, Addis Ababa, Ethiopia. Accessed on March 3, 2015 from https://www.leatherchemists.org/sltc test methods.asp

SLC (Society for Leather - Chemical test) (1996b). Official methods of analysis (SLC-4) for determination of fats and other soluble substances in leather. Leather and Leather products Technology Institute, Addis Ababa, Ethiopia. Accessed on March 3, 2015 from https://www.leatherchemists.org/sltc test methods.asp

SLC (Society for Leather - Chemical test) (1996c). Official methods of analysis (SLC-208) for determination of chromium in leather. Leather and Leather products Technology Institute, Addis Ababa, Ethiopia. Accessed on May 1, 2015 from https://www.leatherchemists.org/ sltc test methods.asp

Stosic, P. (1994). Biological factors influencing the nature of goat skins and leather. Masters thesis. University of Leicester, UK.

Tadesse, D., Urge, M., Animut, G., and Mekasha, Y. (2015). Effects of diet on leather quality and longissimus muscle composition of three Ethiopian indigenous goat types. Animal Production Science. CSIRO PUBLISHING. Accessed on January 7, 2016 from http://dx.doi.org/10.1071/AN14961

Tamire, H. (1986). Retrospects and Prospects of Agricultural Research and Extension. Part II. Developments of Research Stations, Alemaya University of Agriculture, Alemaya, Ethiopia.

Tsegay, T., Mengistu, U., Yoseph, M. (2012). Skin/leather quality of indigenous and crossbred (Dorper $x$ Indigenous) F1 sheep. Livestock Research for Rural Development. Accessed on February 11, 2015 from http://www.irrd.org /irrd24/4/tek124056.htm. Accessed 16 June 2104.

UNIDO (United Nation International Organization) (1994). Acceptable quality standards in the leather and footwear industry. 88p

Van Soest, P.J., Robertson, J.B., Lewis, B.A. (1991). Methods for dietary fiber, neutral detergent fiber and nonstarch polysaccharides in relation to animal nutrition. Journal of Dairy Science 74: 3583-3597.

Whiteman, P.C. (1980). Tropical pasture science. Oxford University Press, Oxford, p. 392. 